INDO GLOBAL JOURNAL OF

PHARMACEUTICAL SCIENCES

ISSN 2249- 1023

\title{
Antibiotic Resistance Pattern in Developing Countries
}

\author{
Aliyu Isa ${ }^{1 *}$, Yusuf A. Isa ${ }^{2}$, Ibrahim Muhammad ${ }^{2}$, Hadiza Bunu Goni ${ }^{2}$ \\ ${ }^{1}$ Department of Biotechnology, Lovely Professional University, Punjab - India \\ ${ }^{2}$ Department of Science Laboratory Technology, Ramat Polytechnic Maiduguri \\ Address for Correspondence: Aliyu Isa; isliyugunda2@gmail.com
}

Received:

01.03.2019

Accepted:

25.03.2019

Keywords

Antibiotic;

Resistance;

Infection.
ABSTRACT: Medicines used for prevention and treatment of infection particularly bacterial infections are referred to as an antibiotic. Antibiotic is administered after surgery to kill potential infectious agents, while it is been prescribe after the manifestation of clinical sign and symptoms as well as laboratory diagnosis. Antibiotic is administered to inactivate bacteria responsible for food poisoning, wounds sepsis, respiratory tract infection, sexually transmitted infection, gastrointestinal tract infection, urinary tract infection etc. However, under certain condition bacteria developed a mechanism(s) that inactivate the bacteriostatic or bactericidal effects of the antibiotic and hence antibiotic resistance occurred. Consequently, prolong hospitalization and treatment, increase medical bill and mortality become widespread. Health care awareness, personal hygiene, agricultural products, food and industrial practices, the proliferation of substandard drugs, self-medication are some of the causes of antibiotic resistance in developing countries. () 2019 iGlobal Research and Publishing Foundation. All rights reserved.

Cite this article as: Isa, A.; Isa, Y.A.; Muhammad, I.; Goni, H.B. Antibiotic Resistance Pattern in Developing Countries. Indo Global J. Pharm. Sci., 2019; 9(2Suppl.): 123. DOI: http://doi.org/10.35652/IGJPS.2019.92S21

Indo Global Journal of Pharmaceutical Sciences( ISSN 2249 1023; CODEN- IGJPAI; NLM ID: 101610675) indexed and abstracted in CrossRef (DOI Enabling), UGC CARE Journal List, EMBASE(Elsevier), National Library of Medicine (NLM) Catalog, ResearchGate, Publons, CAS (ACS), Index Copernicus, Google Scholar and many more. For further details, visit http://iglobaljournal.com

This is a special issue as an outcome of 'RAPSCON-2019' sponsored by APTI and organized by Sri Sai College of Pharmacy, Manawala, Amritsar, Punjab, India. Relaxation offered in journal format. 